\title{
Research on Initial Restoration Effect of Vegetation Based on Deep-processing Material of Surface Resources on Expressway Slope
}

\author{
Cao Zilong ${ }^{1,}$, , Chen Shuxue $\mathrm{e}^{1, \mathrm{~b}}$ \\ ${ }^{1}$ China Academy of Transportation Science, Beijing, 100029 \\ acaozilong@126.com, ${ }^{b}$ chenshuxue@moccats.com.cn
}

Keywords: surface soil of fine particles; compost; soil substrate; expressway slope; vegetation restoration

\begin{abstract}
With deep-processing material of surface resources as soil substrate, the experiment of soil spray sowing was carried out on expressway slope. The results show that taking surface soil of fine particles and compost product of surface organic plant residue as the main soil substrate for slope soil spray-sowing greening in the initial vegetation restoration can significantly speed up the vegetation propagation velocity on the side slopes, which can promote slope vegetation to maintain reasonable proportion of grass and shrub, help to increase the diversity of the communities, and promote the slope vegetation community to evolve toward the native direction.

Surface resources obtained by surface cleaning in development and construction projects are valuable ones that can be reused. The related researches show that the valuable surface resources contain not only rich organic matter, nitrogen, phosphorus, potassium and other nutrients, but also soil seed bank consisting of livable seeds which are the potential plant population or community as well as the material basis of naturally updating the vegetations [1]. USA, Japan and other developed countries have attached great importance to topsoil stripping and utilization, formed a mature management system and technical means, and carried out related researches on vegetation restoration effect of topsoil utilization [2-4]. Researches show that the backfilling and utilization of natural topsoil after stripping can increase the biological diversity in the soil [5-6], and also speed up the vegetation succession which is available for early development of local shrub [7].In recent years, more and more attention has been paid to topsail utilization in highway construction, and some practical applications are carried out in the process of some highway constructions [8-10]. However, surface resource utilization in the process of highway construction is still stuck in the simple level of backfilling utilization, and some clear researches on deep-processing and comprehensive utilization of topsoil and organic plant residues on the surface obtained by surface cleaning in highway construction have not been reported. To implement the in-depth study on making full use of surface resources in vegetation restoration on the sides of highway, protect the ecological environment of soil source area, promote the formation of shrub and grass vegetation, solve the intensive grass-based problems in spray-sowing greening, the research has relied on Guangzhou-to-Lechang expressway project, made surface soil of fine particles and residue compost product of surface organic plant as the main soil substrate of slope soil, and combined with spraying technology to carry out practical researches for a useful attempt to further exploring the technology of deep-processing and comprehensive utilization of surface resources in vegetation restoration of highway side slopes through contrast test of the restoration effect on vegetation.
\end{abstract}

\section{Overview of Research Areas}

This research relies on the project of Guangzhou-to-Lechang highway construction. The experimental section is located in Shaoguan City, Guangdong Province. The climate of the research region is subtropical humid monsoon, and it is affected by the monsoon throughout the year with northeast monsoon prevailing in winter and southwest and southeast monsoon prevailing in summer. In the region, the average rainfall is $1700 \mathrm{~mm}$, the evaporation capacity is $1530 \mathrm{~mm}$, the annual average sunshine hours is $1723.8 \mathrm{~h}$, the annual average temperature is $21^{\circ} \mathrm{C}$ and there are 310 days without frost throughout the year. Soil types are mainly as lateritic red soil. 


\section{Research Methods}

\subsection{Setting of Experimental Slope}

This research takes the right side slope of Guangzhou-to-Lechang highway (whose stake number is LK18 $180 \sim$ LK18 330) as experimental slope. The side slope has a height of $25 \mathrm{~m}$ and a slope ratio of $1: 1$, belonging to the strong weathered rock slope. The side slope is divided into 3 levels. Among them, Levels 1 and 2 of side slopes are set as the experimental ones, and Level 3 slope namely the top slope is set as the control slope.

\subsection{Experimental Material}

\subsubsection{Soil Substrate on Experimental Slop}

The research takes the surface soil of fine particles and the residue compost product of surface organic plant as the main soil substrate of slope soil. The specific production process is as follows:

Surface resources produced by surface cleaning on the experimental slopes are stacked in the spoil ground on the right of side slope and taken with temporary protections. Then the collected surface resources shall be classified to sort out big and thick objects (such as large stones and branches) manually, and then carry out sieving to obtain the surface soil of fine particles and surface organic plant residues (such as branches, leaves, shrub and grass, etc.).With the obtained organic plant residues as compost materials, the forced aeration static pile composting system is adopted for composting. During the period of composting and fermentation, the ventilation lasts 20 min every day with re-composting one time every seven days, and the total composting time will be 65 days. At last, the compost product of surface organic plant residue will be formed.

\subsubsection{Soil Substrate on Control Slop}

Non-surface soil in the same area of experimental section is taken as the soil material of control side slope, and added with a certain proportion of peat soil.

\subsection{Experimental Scheme}

\subsubsection{Construction Technology}

Both experimental and control slopes chosen for the experiment can adopt the soil spray sowing technology to carry out construction.

\subsubsection{Material Proportioning Scheme}

The surface soil of fine particles and the compost product of plant organic residue were taken as the soil material of experimental slope, while non-surface soil and peat soil were taken as the soil material of control slope. The proportioning ratio between the surface soil of fine particles and the compost product of plant organic residue was classified with three levels of $\mathrm{A}, \mathrm{B}$, $\mathrm{C}$, and the proportioning scheme is shown in Table 1.

Table 1 Proportioning Scheme of Soil Substrate on Experimental and Control Slopes

\begin{tabular}{c|c|c|c|c|c}
\hline \multirow{2}{*}{ Item } & \multirow{2}{*}{ Unit } & $\begin{array}{c}\text { Surface soil } \\
\text { of fine } \\
\text { particle }\end{array}$ & $\begin{array}{c}\text { Non-surface } \\
\text { soil }\end{array}$ & $\begin{array}{c}\text { Compost } \\
\text { product of } \\
\text { organic surface }\end{array}$ & Peat soil \\
\cline { 3 - 6 } & & 60 & 0 & 40 & 0 \\
Experimental slopes & $\%$ & 50 & 0 & 50 & 0 \\
Experimental slopes & $\%$ & 40 & 0 & 60 & 0 \\
Control slopes & $\%$ & 0 & 60 & 0 & 40 \\
\hline
\end{tabular}

\subsubsection{Proportioning Scheme of Plant Species}

In order to increase the comparability of experimental and control slope, the same proportioning scheme was selected for spray sowing species on experimental and control slope, and the proportioning scheme of plant species is shown in Table 2. 
Table 2 Proportioning Scheme of Spray Sowing Species on Experimental and Control Slopes

\begin{tabular}{l|c|c|c|c}
\hline \multirow{2}{*}{\multicolumn{1}{c|}{ Name of Plant }} & \multicolumn{4}{|c}{ Design Capacity (g/m $\left.{ }^{2}\right)$} \\
\cline { 2 - 5 } & $\begin{array}{c}\text { Experimental } \\
\text { slopes (A) }\end{array}$ & $\begin{array}{c}\text { Experimental } \\
\text { slopes (B) }\end{array}$ & $\begin{array}{c}\text { Experimen } \\
\text { tal }\end{array}$ & $\begin{array}{c}\text { Control } \\
\text { slopes }\end{array}$ \\
\hline Cynodondactylon & 1 & 1 & 1 & 1 \\
Indigofera amblyatha & 3 & 3 & 3 & 3 \\
Rhus chinensis Mill & 3 & 3 & 3 & 3 \\
Lespedeza floribunda Bunge & 2 & 2 & 2 & 2 \\
Leucanea leucocephala & 2 & 2 & 2 & 2 \\
Tephrosia candida DC & 1 & 1 & 1 & 1 \\
\hline
\end{tabular}

\subsubsection{Construction Time}

Since there was a difference of completion time between experimental and control slopes, the experiment time of soil spray sowing was different. The construction time of experimental slopes was from April 27 to 29, 2013; and that of control slope was from April 12 to 13, 2013. The same way of curing was adopted after spray sowing greening on experimental and control slopes.

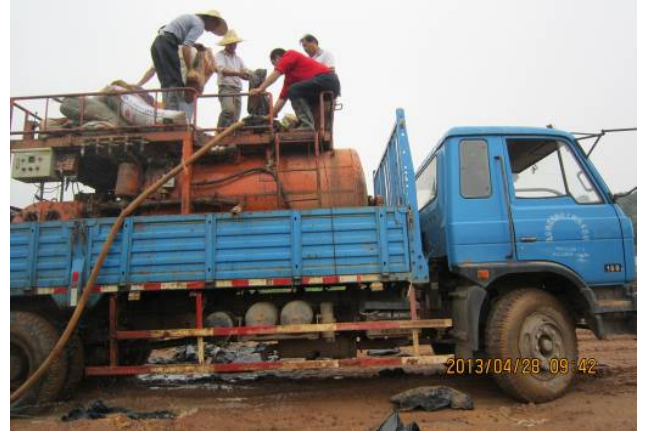

Fig. 1 Experimental Substrate Mixture for Soil Spray Sowing 2.4 Observation of Plants on Side Slope

(1) Quadrat Setup. Adopt the random sampling quadrat, and then fix the quadrat observation method. The experimental and control slopes were set randomly with three pieces of fixed observation quadrat. The specification of each quadrat is $1 \mathrm{~m} \times 1 \mathrm{~m}$, and its four corners are fixed with small stakes to form four edges with a string.

(2) Observation index. This research is mainly to observe the seedling emergence and early growth condition, and select plant species, numbers, coverage and height as the observation indexes. Coverage is determined by the sample point method [11].

(3) Observation time and frequency. Within 60 days after soil spray sowing, observe the fixed observation plots on the experimental and control slopes every 10 days. After that, observe them monthly until October 2013 that the first growing season is ended.

\section{Result and Analysis}

3.1 Evaluation and Analysis of Vegetation Propagation Velocity on Slope

The vegetation propagation velocity on slopes is essential for the vegetation restoration effect on expressway slopes. In this experiment, after soil spray sowing, the two indexes of the average height and coverage of experimental and control slopes will reflect the vegetation propagation velocity on the slopes. These two indicators are the important factors of vegetation for controlling and reducing the soil erosion on highway slopes effectively.

\subsubsection{Changes in Average Height of Vegetation}

As shown in Figure 3, the average height changes of herbaceous plants on the three experimental slopes (A, B, C) in the first growing season were faster significantly than that on the control slope, namely, herbaceous plants on three slopes grew faster than that on the control slope. In accordance with the observation data of May, the average height of herbaceous plants on the control slope was 
more than that on the three experimental slopes because it was 15 days earlier for spray sowing greening on the control slope than that on experimental slopes. In June, the average height of herbaceous plant on three slopes gradually exceeded that on the control slope, and the average height of herbaceous plant on experimental slopes was greater significantly than that on the control slope at the end of the first growth season. The average height of herbaceous plants on experimental slopes was 1.23 times, 1.26 times and 1.30 times respectively of that on the control slope. In addition, we can also see that there is no obvious difference among the average height of herbaceous plants on the three experimental slopes (A, B, C) in the first growing season, as shown in Figure 3.

As shown in Figure 4, the average height changes of shrub on the three experimental slopes (A, B, C) in the first growing season were faster significantly than that on the control slope, namely, shrub on three slopes grew faster than that on control slope. The average height of shrub on the experimental slopes was greater significantly than that on the control slope at the end of the first growth season. The average height of shrub on the experimental slopes was 1.86 times, 1.87 times and 1.86 times respectively of that on the control slope. In addition, we can also see that there is no obvious difference among the average height of shrub on three slopes (A, B, C) in the first growing season, as shown in Figure 4.


Fig. 3 Average Height of Herbaceous Plant on Experimental and control slopes

\subsubsection{Changes in Average Coverage of Vegetation}

As shown in Figure 5, the average coverage of vegetation on the control slope was larger slightly than that on the three experimental slopes (A, B, C), because the time of spray sowing greening on the control slope was 15 days earlier than that on the experimental slopes. In the last ten-day period of May, the average coverage of vegetation on the three experimental slopes (A, B, C) exceeded that on the control slope gradually, and the average coverage of vegetation on the experimental slopes was higher slightly than that on the control slope at the end of the first growth season. The average coverage of vegetation on the experimental slopes was 1.05 times, 1.06 times and 1.05 times respectively of that on the control slope. In addition, we can also see that there is no obvious difference among the average coverage of vegetation on the three experimental slopes $(A, B, C)$ in the first growing season, as shown in Figure 5.

The above research results show that the vegetation propagation velocity on the experimental slopes with the surface soil of fine particles and the compost product of plant organic residue as the main soil substrate was faster obviously than that on the control slope with non-surface soil and peat soil as the main oil substrate.

3.2 Evaluation and Analysis on Grass and Shrub Proportion of Vegetation on Slopes

The grass and shrub proportion is a key factor in determining the stability and good succession of target community. Also it is an index which is difficult mostly to control in soil spray sowing. In the early period for planting the vegetation on slopes, too large herbage density will lead to decreasing shrub seedlings gradually, and communities will develop toward the direction of single herb community. Therefore, it is essential for the vegetation restoration effect on slopes by controlling the grass and shrub proportion.

As shown in Figure 6, the grass and shrub proportion on the three slopes remained between 3.15 and 9.83 in the first growing season, while that on the control slope was greater significantly than that on the three slopes reaching between 10.28 and 27.51. In addition, the grass and shrub proportion on the control slope increased gradually from the beginning of the initial vegetation propagation, while that on the experimental slopes was relatively stable. This indicates that the 
greater herbaceous density on the control slope will result in decreasing the shrub seedlings gradually, and communities will develop toward the direction of single herb community. However, the grass and shrub density on the experimental slopes is more appropriate, which is more conducive to the community developing towards the direction of diversification. These research results also show that it can promote effectively to maintain a good grass and shrub proportion by adding surface soil of fine particle to the soil substrate, and provide a good soil environment for the succession from slope vegetation to native vegetation community.

In addition, it can also be seen in Figure 6 that the proportion of the fine particles of surface soil and the compost product of organic plant residues on the three experimental slopes is different, and the grass and shrub proportion change of slope vegetation is more different obviously over time. It reflects specifically that the grass and shrub proportions of three slope vegetations such as (A), (B) and $(\mathrm{C})$ are similar in the initial vegetation propagation, and the grass and shrub proportion of the experimental slopes is $3.15,3.20$, and 3.22 respectively. As time goes by, the grass and shrub proportion of the experimental slope $(\mathrm{C})$ had the fastest change followed by that of the experimental slope (B), and the grass and shrub proportion of the experimental slope (A) was most stable relatively. At the end of the first growing season, the grass and shrub proportion of the experimental slopes (A), (B), (C) were 2.13, 2.55, and 3.05 times respectively of that in the initial vegetation propagation. This indicates that the proportion program of the experimental slope (A), namely surface soil of fine particles in soil substrate accounted for $60 \%$ among the proportion scheme of soil substrates on the three experimental slopes while the organic compost plant residues accounted for $40 \%$, and can promote to maintain a reasonable grass and shrub proportion of slope vegetation.

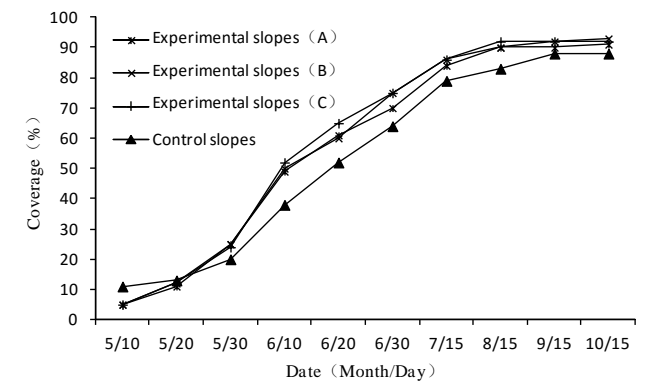

Fig. 5 Average Vegetation Coverage of Experimental and Control Slopes

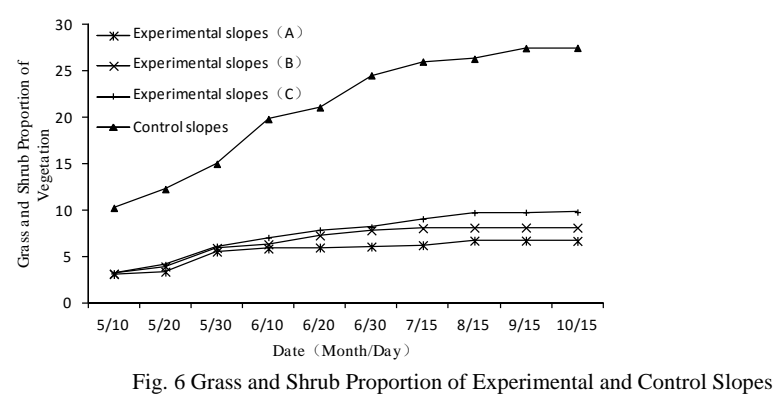

Fig. 6 Grass and Shrub Proportion of Experimental and Control Slopes

3.3 Evaluation and Analysis of Vegetation Community Composition on Slope

3.3.1 Changes in Plant Species and Quantity

The plant species and quantity is an important index that reflects the diversity of vegetation community species in a certain region. As shown in Figure 7 , there are five and four species respectively on the experimental and control slopes with little difference in the initial vegetation propagation according to the observation data on May 10. Since then, the plant species and quantity had increased rapidly. At the end of the first growing season, the species and quantity of the experimental slopes (A) and (B), (C) had reached 12, 10 and 10 respectively with an increase by 7, 5 , and 5 while the species and quantity of plants on the control slopes at the end of the first growth reached 5 increased only by 1 , and there was not any difference by comparing with the initial vegetation propagation. The species and quantity of plants on the control slopes were $41.67 \%$, $50.00 \%$, and $50.00 \%$ respectively of that on the experimental slopes (A), (B) and (C).






\subsubsection{Composition Analysis of Plant Community}

The change in the composition of slope vegetation community was an important manifestation of vegetation succession. As shown in Tables 3 to 6, there are five species of Bermudagrass, Magnolia multiflora, Dodonaea viscose, Leucaena, and Tephrosia whose seeds were added by manual soil spray sowing in the initial vegetation period of three experimental slopes according to the observation data on May 10. Since then, the species had increased gradually . At the end of the first growing season, besides six kinds of slope surface plants seeds by soil spray sowing, another 6 species of wild plant species such as Eriocaulon buergerianum, Clerodendron fragrans, Artemisia annua L., Amaranthus tricolor, Echinochloa crusgalli and Stellaria media appeared successively on the experimental slope (A). There were also 4 kinds of wild plants appearing on the experimental slopes (B) and (C).

Comparatively speaking, there are 4 kinds of slope plant species such as Bermudagrass, Magnolia multiflora, Dodonaea viscose and Tephrosia whose seeds were added by manual soil spray sowing according to the observation data on May 10. Since then, the species increased only a little. At the end of the first growing season, five plant species whose seeds were added additionally by manual soil spray sowing, there was not any wild plant appearing at all.

These research results show that the experimental slopes with the surface soil of fine particles and the compost product of plant organic residue as the main soil substrate are conducive to the promotion of community diversity. The soil on the experimental slopes is more suitable for the growth of some wild plant species, which is conducive to the promotion of slope vegetation community for developing toward the native direction. At the same time, they also show that the surface soil of fine particles added into soil spray sowing contains some wild plant seeds which are conducive to the promotion of the vegetation succession.

Table 3 Plant Species and Quantity on Experimental Slopes (A)

\begin{tabular}{|c|c|c|c|c|c|}
\hline \multirow[b]{2}{*}{$\begin{array}{c}\text { Observation } \\
\text { date }\end{array}$} & \multicolumn{4}{|l|}{ Plant Species } & \multirow{2}{*}{$\begin{array}{l}\text { Total of } \\
\text { plant } \\
\text { species } \\
\text { and } \\
\text { quantity }\end{array}$} \\
\hline & Spray sowing plant species & $\begin{array}{l}\text { Plant } \\
\text { species } \\
\text { and } \\
\text { quantity }\end{array}$ & Wild plant species & $\begin{array}{l}\text { Plant } \\
\text { species } \\
\text { and } \\
\text { quantity }\end{array}$ & \\
\hline May 10 & $\begin{array}{l}\text { Bermudagrass,Magnolia.multiflora, Dodonaea,viscose, } \\
\text { Leucaena, and Tephrosia }\end{array}$ & 5 & & 0 & 5 \\
\hline June 10 & $\begin{array}{l}\text { Bermudagrass,Magnolia multiflora, Dodonaea viscose, } \\
\text { Leucaena, Rhus chinensis and Tephrosia }\end{array}$ & 6 & $\begin{array}{l}\text { pipewort, fragrant } \\
\text { glorybower root or } \\
\text { leaf, southernwood, } \\
\text { amaranth, barnyard } \\
\text { grass, }\end{array}$ & 5 & 11 \\
\hline July 15 & $\begin{array}{l}\text { Bermudagrass,Magnolia multiflora, Dodonaea viscose, } \\
\text { Leucaena, Rhus chinensis and Tephrosia }\end{array}$ & 6 & $\begin{array}{l}\text { Pipewort, fragrant } \\
\text { glorybower root or } \\
\text { leaf, southernwood, } \\
\text { amaranth, barnyard } \\
\text { grass. }\end{array}$ & 5 & 11 \\
\hline August 15 & $\begin{array}{l}\text { Bermudagrass,,Magnolia multiflora, Dodonaea viscose, } \\
\text { Leucaena, Rhus chinensis and Tephrosia }\end{array}$ & 6 & $\begin{array}{l}\text { Pipewort, fragrant } \\
\text { glorybower root or } \\
\text { leaf, southernwood, } \\
\text { amaranth, barnyard } \\
\text { grass, chickweed }\end{array}$ & 6 & 12 \\
\hline $\begin{array}{l}\text { September } \\
15\end{array}$ & $\begin{array}{l}\text { Bermudagrass, Magnolia multiflora, Dodonaea viscose, } \\
\text { Leucaena, Rhus chinensis and Tephrosia }\end{array}$ & 6 & $\begin{array}{l}\text { Pipewort, fragrant } \\
\text { glorybower root or } \\
\text { leaf, southernwood, } \\
\text { amaranth, barnyard } \\
\text { orass rhirkweed }\end{array}$ & 6 & 12 \\
\hline
\end{tabular}


\begin{tabular}{l|l|} 
October 15 & $\begin{array}{l}\text { Bermudagrass, Magnolia multiflora, Dodonaea viscose, } \\
\text { Leucaena, Rhus chinensis and Tephrosia }\end{array}$
\end{tabular}

Table 4 Plant Species and Quantity on Experimental Slopes (B)

\begin{tabular}{|c|c|c|c|c|c|}
\hline \multirow[b]{2}{*}{$\begin{array}{l}\text { Observation } \\
\text { date }\end{array}$} & \multicolumn{4}{|c|}{ Plant Species } & \multirow{2}{*}{$\begin{array}{l}\text { Total of } \\
\text { plant } \\
\text { species } \\
\text { and }\end{array}$} \\
\hline & Spray sowing plant species & \begin{tabular}{|l} 
Plant \\
species \\
and
\end{tabular} & Wild plant species & \begin{tabular}{|l} 
Plant \\
species \\
and
\end{tabular} & \\
\hline May 10 & $\begin{array}{lr}\text { Bermudagrass, } & \text { Magnolia } \\
\text { multiflora, Dodonaea } & \text { viscose, } \\
\text { Leucaena, and Tephrosia } & \end{array}$ & 5 & & 0 & 5 \\
\hline June 10 & 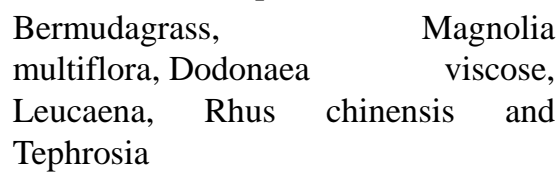 & 6 & $\begin{array}{l}\text { Pipewort, fragrant } \\
\text { glorybower root or leaf, } \\
\text { amaranth, }\end{array}$ & 3 & 9 \\
\hline July 15 & 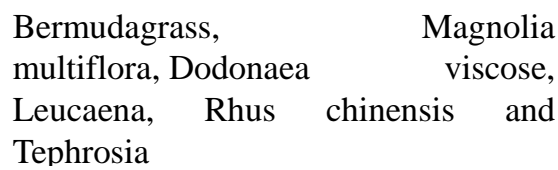 & 6 & $\begin{array}{l}\text { Pipewort, fragrant } \\
\text { glorybower root or leaf, } \\
\text { southernwood, amaranth, }\end{array}$ & 4 & 10 \\
\hline August 15 & $\begin{array}{l}\text { Bermudagrass, } \\
\text { multiflora, Dodonaea }\end{array} \begin{array}{r}\text { Magnolia } \\
\text { Leucaena, Rhus cose, } \\
\text { Tebhrosia }\end{array}$ & 6 & $\begin{array}{l}\text { Pipewort, fragrant } \\
\text { glorybower root or leaf, } \\
\text { southernwood, amaranth, }\end{array}$ & 4 & 10 \\
\hline $\begin{array}{c}\text { September } \\
15\end{array}$ & 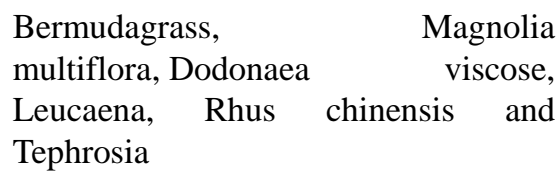 & 6 & $\begin{array}{l}\text { Pipewort, fragrant } \\
\text { glorybower root or leaf, } \\
\text { southernwood, amaranth, }\end{array}$ & 4 & 10 \\
\hline October 15 & $\begin{array}{l}\text { Bermudagrass, } \\
\text { multiflora, Dodonaea } \\
\text { Leucaena, Rhus chinolia } \\
\text { Tenhrosia }\end{array}$ & 6 & $\begin{array}{l}\text { Pipewort, fragrant } \\
\text { glorybower root or leaf, } \\
\text { southernwood, amaranth, }\end{array}$ & 4 & 10 \\
\hline
\end{tabular}

Table 5 Plant Species and Quantity on the Experimental Slopes (C)

\begin{tabular}{|c|c|c|c|c|c|}
\hline \multirow[b]{2}{*}{$\begin{array}{l}\text { Observation } \\
\text { date }\end{array}$} & \multicolumn{4}{|c|}{ Plant Species } & \multirow{2}{*}{$\begin{array}{c}\text { Total of } \\
\text { plant } \\
\text { species } \\
\text { and } \\
\end{array}$} \\
\hline & Spray sowing plant species & $\begin{array}{l}\text { Plant } \\
\text { species and } \\
\text { quantity }\end{array}$ & Wild plant species & $\begin{array}{l}\text { Plant } \\
\text { species and } \\
\text { quantity }\end{array}$ & \\
\hline May 10 & $\begin{array}{lr}\text { Bermudagrass, } & \text { Magnolia } \\
\text { multiflora, Dodonaea viscose, Leucaena, } \\
\text { and Tephrosia }\end{array}$ & 5 & & 0 & 5 \\
\hline June 10 & $\begin{array}{lr}\text { Bermudagrass, } & \text { Magnolia } \\
\text { multiflora, Dodonaea viscose, Leucaena, } \\
\text { Rhus chinensis and Tephrosia }\end{array}$ & 6 & Pipewort, & 1 & 7 \\
\hline July 15 & $\begin{array}{l}\text { Bermudagrass, } \\
\text { multiflora, Dodonaea viscose, Leucaena, } \\
\text { Rhıc rhinancic and Tonhrncia }\end{array}$ & 6 & $\begin{array}{l}\text { Pipewort, fragrant } \\
\text { glorybower root or leaf, } \\
\text { amaranth }\end{array}$ & 3 & 9 \\
\hline August 15 & $\begin{array}{l}\text { Bermudagrass,Magnolia } \\
\text { multiflora, Dodonaea viscose, Leucaena, } \\
\text { Rhus chinensis and Tephrosia }\end{array}$ & 6 & $\begin{array}{l}\text { Pipewort, fragrant } \\
\text { glorybower root or leaf, } \\
\text { amaranth, }\end{array}$ & 3 & 9 \\
\hline
\end{tabular}




\begin{tabular}{c|l|lr|l|c|c}
$\begin{array}{c}\text { September } \\
15\end{array}$ & $\begin{array}{l}\text { Bermudagrass, } \\
\text { multiflora, Dodonaea viscose, Leucaena, } \\
\text { Rhus chinensis and Tephrosia }\end{array}$ & 6 & $\begin{array}{l}\text { Pipewort, fragrant } \\
\text { glorybower root or leaf, } \\
\text { amaranth, }\end{array}$ & 3 & 9 \\
October 15 & $\begin{array}{l}\text { Bermudagrass, Magnolia } \\
\text { multiflora, Dodonaea viscose, Leucaena, } \\
\text { Rhus chinensis and Tephrosia }\end{array}$ & 6 & $\begin{array}{l}\text { Pipewort, fragrant } \\
\text { glorybower root or leaf, } \\
\text { southernwood, amaranth, }\end{array}$ & 4 & 10 \\
\hline
\end{tabular}

Table 6 Plant Species and Quantity on Control Slopes

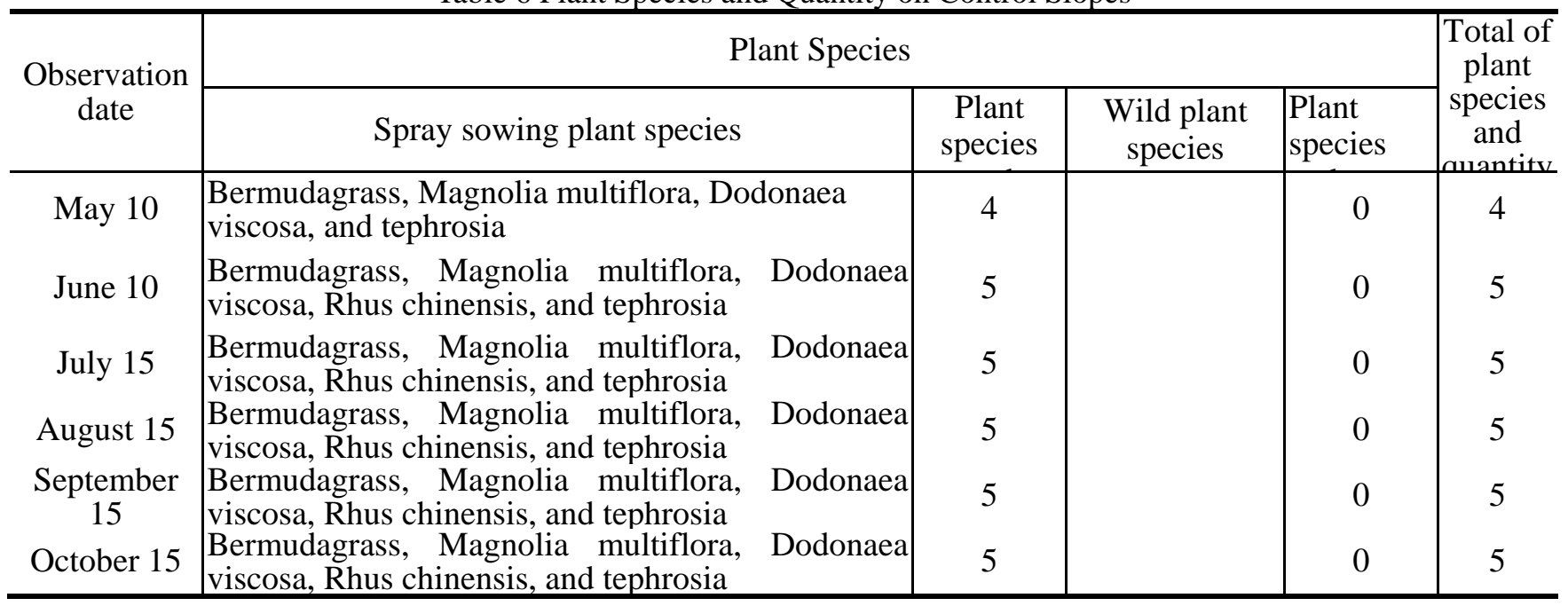

\section{Conclusion}

(1) After soil spray sowing, the vegetation propagation velocity in the initial vegetation restoration on the experimental slopes with the surface soil of fine particles and the compost product of plant organic residue as the main soil substrate is faster than that on the control slope with the non-surface soil and the peat soil as the main soil substrate.

(2) The grass and shrub density on the experimental slopes with the surface soil of fine particles and the compost product of plant organic residue as the main foreign soil substrate is more suitable, which is more conducive to the community evolving toward the direction of diversification. For the control slope with the non-surface soil and the peat soil as the main soil substrate, the herbaceous with excessive density will lead to shrub seedlings decreasing gradually, and the community evolves toward the direction of the single herb community.

(3) The experimental slopes with the surface soil of fine particles and the compost product of plant organic residue as the main soil substrate is conducive to the promotion of community diversity. It is more suitable for the growth of some wild plant species, and is conducive to the promotion of slope vegetation community evolving towards the direction of the native. At the same time, it also shows that the surface soil added to the substrate by soil spray sowing containing some seeds of wild plant is conducive to the promotion of the vegetation succession.

\section{References}

[1] Moles AT, Drake DR. Potential contribution of the seed rain and seed bank to regeneration of native forest under plantation pine in New Zealand[J]. New Zealand Journal of Botany, 1999,(37):83-93.

[2] Brown G, Al Mazrooei S. Rapid vegetation regeneration in a seriously degraded Rhanterium epapposum community in northern Kuwait after 4 years of protection[J]. Journal of Environmental Management, 2003,(68):387-395. 
[3] ZHU Xian-yun The Practice and Characteristics of Foreign Topsoil Stripping[J] . Natural Resource Economics of China. 2009,(9):24-26.

[4] Liu Xin-wei. Utilization and Improvement Measure of Topsoil Stripping in Japan [J].Land \& Resources, 2008,(9):52-55.

[5] Depuit E J. Potential topsoiling strategies for enhancement of vegetation diversity on mined lands[J]. Minerals and the Environment, 1984,6(3):115-120.

[6] Schladweiler B K, Vance G F, Legg D E, et al. Topsoil depth effects on reclaimed coal mine and native area vegetation in northeastern Wyoming[J]. Rangeland Ecology \& Management, 2005,58(2):167-176.

[7] Alday J G, Marrs R H. Vegetation succession on reclaimed coal wastes in Spain: the influence of soil and environmental factors[J]. Applied Vegetation Science, 2011,14(1):84-94.

[8] WANG Wei-gang ,ZHANG Qian-feng,LI Neng. Application and Practice of Clear Topsoil in Highway Landscape Engineering [J]. Journal of Highway and Transportation Research and Development, 2012,(12):358-361.

[9] LIN Cai-kui. Technical Research on Slop Greening with Topsoil in Guangzhou - Wuzhou Expressway [J]. Highway, 2010,(1):193-195.

[10] WANG Ti,TAO Shuang-cheng,KONG Ya-ping. Application of topsoil resources in ecological restoration of gentle slopes along Pengze-Hukou highway,Jiangxi Province. [J]. Chinese Journal of Ecology,2012,31(1):172-179.

[11] REN Ji-zhou. Research Methods on Pratacultural Science [M].BeiJing:China Agriculture Press,1998.

Note:

Fund Project: the science and technology project "Building a Complete Set of Technology Research on Guangzhou-to-Lechang Expressway” (Project Number: 200901001) under Guangdong Provincial Department of Transportation.

First Author: Cao Zilong (1978- ), male, Associate Researcher, Ph. D. from Beijing Forestry University, mainly engaged in related research on transportation and environmental protection in China Academy of Transportation Science.

Co-author: Chen Shuxue (1980- ), female, Assistant Researcher, Master from Nankai University, mainly engaged in related researches on environmental protection and energy conservation and emission reduction in transportation in China Academy of Transportation Science. 
